\title{
Examining High-performing Education Systems in Terms of Teacher Training: Lessons Learnt for Low-performers
}

\author{
Erkan Çer $^{1, *} \&$ Ekrem Solak ${ }^{1}$ \\ ${ }^{1}$ Faculty of Education, Amasya University, Amasya, Turkey \\ *Correspondence: Faculty of Education, Amasya University, Amasya, Turkey. E-mail: erkan.cer@amasya.edu.tr
}

Received: February 28, 2017

Accepted: January 17, 2018 Online Published: February 7, 2018

doi:10.5430/jct.v7n1p42

URL: https://doi.org/10.5430/jct.v7n1p42

\begin{abstract}
The quality of a teacher plays one of the most important roles in the achievement of an education system. Teacher training is a multi-dimensional process which comprises the selection of teacher candidates, pre-service training, appointment, in-service training and teaching practices. Therefore, this study focuses on teacher training processes in Singapore, Shanghai-China, Hong Kong-China and Turkey and aims to discover the reasons for success in Program for International Student Assessment (PISA) by relating it with teacher training processes. Singapore, Shanghai-China, Hong Kong-China were chosen to study because their educational systems were ranked among the high-performing educational systems in 2016. This study was a qualitative research and document analysis method was used to collect data about the relevant countries' teacher training processes. The result of the study suggested some practical considerations for teacher training programs in low-performing education systems about the selection of teacher candidates, pre-service training, appointment, in-service training and teaching practices.
\end{abstract}

Keywords: teacher training, PISA, high-performing education systems, Singapore, Turkey

\section{Introduction}

Education is a system which contributes to personal development and helps individuals to acquire the necessary information, skill and competence to be a member of a society (Oğuzkan, 1974). In this sense, the purpose of an education system is to train individuals who comply with changes resulting from technological improvements and globalization in accordance with the modernization (Gopinathan \& Sharpe, 2007). From this point of view, a teacher plays one of the most important roles in the education and training of individuals. Because a teacher is an actor who understands how learning patterns display variability and how an individual is exposed to cognitive, social, linguistic, physical and affective domains, who designs and implements learning environments appropriate for learners' learning styles (Borich, 2014). A teacher is also involved in interaction with learners during the teaching and learning process (Day \& Gu, 2010), implements, manages and evaluates both teaching programs and learners (Grossman, 1990), enhances the quality of educational services, updating her/his knowledge permanently, effective in the communication and interaction process, uses the teaching methods, techniques, strategies effectively by stimulating linguistic, audio-visual tactile senses (Richman et al., 2013). In this context, although an educational system has different variables in terms of learner, teaching programs, teaching and teacher process (Aykaç, 2005), a teacher is the key element who helps to work interactively, collaboratively and productively among these variables (Harris \& Sass, 2011).

Teacher training is a multi-dimensional process which comprises the selection of teacher candidates, pre-service training, teaching practices, observation and evaluation of the process (Kavcar, 2002). In this process, prospective teachers need to be trained in a qualified way in their profession during pre-service training (Sönmez, 2003). Because, the quality of content, pedagogical and world knowledge of pre-service teachers will contribute the re-structure of the teaching process in pre-school, primary school and high school period in a large extent. In this sense, although there is no common understanding in teacher training due to different culture, management and tradition (Şişman, 2009), an approach is required for teacher candidates aiming to give priority to linguistic, personal, affective and social development, to learn how to learn together with their students, to research updates, to follow technological advances, to adapt themselves to political, cultural and economic improvements, to get to know their students in all developmental ways and to recognize new teaching theories (Krolak-Schwerdt et al., 2014; Skinner, 2005). Such an 
approach helps to improve not only overcome the problems during teaching process but also raise the quality of the education.

In the literature, plenty of researches can be found how the quality of a teacher influences the teaching process, learning environments and achievement of learners. The improvement in the oral skills of a teacher also helps to advance the same skills in learners though the racial, ethical and level of schooling may change in different learners (Ehrenberg \& Brewer, 1995). The characteristics of a teacher such as experience, performance, planning and skills have a significant effect in learners' achievement (Rivkin et al., 2005; Aaronson et al., 2007). In addition, high level coordination is found between emotions, thoughts and judgements of teachers on learners with that of academic achievement of the learners (Demaray \& Elliott, 1998). On the other hand, there are some researches revealing that the experience acquired by the teacher does not contribute to learners' achievement (Harris \& Sass, 2011). PISA (The Programme for International Student Assessment) can be taken into consideration as an important assessment criterion in determining the correlation between teacher quality and achievement of learners.

\subsection{A Dressing the Problem}

PISA is held once in three years by Organization for Economic Cooperation and Development (OECD) and tests 15 years old students on mathematics, science and reading literacy. It helps authorities in countries to evaluate, revise and compare their educational systems and to find out reasons for success or failure rather than to race students. Since the quality of a teacher is directly related to success of an educational system, PISA results can give clues about the effectiveness of teacher training programs in the relevant countries. Therefore, this study focuses on teacher training processes in Singapore, Shanghai-China, Hong Kong-China and Turkey and aims to discover the reasons for success in PISA by relating it with teacher training process. Singapore, Shanghai-China, Hong Kong-China were chosen to study because their educational systems have been ranked among the high-performing educational systems since 2006 (OECD, 2006, 2009, 2012, 2016b). It is hypothesized that the result of this study can give reliable results on re-structuring low-performing educational systems in terms of teacher training. In this context, following research questions are answered in this study.

In teacher training programs in Singapore, Shanghai-China, Hong Kong-China and Turkey;

What are the requirements in the selection, placement and appointment of teacher candidates?

What is the content and quality of pre-service and in-service training?

What are the principles of teaching practices?

\section{Method}

A qualitative research design was used in this study which aimed to compare teacher training programs in Singapore, Shanghai-China, Hong Kong-China and Turkey. A qualitative research method involves interpreting different concepts, problems, processes and the most common characteristics of this method is to investigate people and events in their natural surroundings (Neuman, 2007). In this aspect, methods like observation, interview and document analysis are commonly used in a qualitative research and perceptions and events are revealed in a realistic way. The researcher attempts to reach a complementary view point about the research topic. The data collected can be divided into meaningful sub-units (Flick, 2009).

\subsection{Data Collection}

Document analysis technique as a qualitative research method was used in this study. Document analysis helps to reach original and current resources related to research topic and to analyze the collected data (Çepni, 2010). Since this study focused on the teacher training programs in Singapore, Shanghai-China, Hong Kong-China and Turkey, the relevant data was collected from official web pages of the ministries of education. The secondary source of data in this study was reports published by OECD and other educational institutions in those countries and other scientific studies made by researchers.

\subsection{Data Analysis}

Descriptive analysis was used in the evaluation of the data collected. Descriptive analysis is to present the qualitative data by quoting the original document, sticking the people's oral and written words (Weber, 1990). In accordance with the purpose of the study, data collected was classified in terms of selection, placement, appointment of teacher candidates, the quality of pre-service and in-service teacher training and teaching practices. These classifications were evaluated by an expert in qualitative studies. As a result of this process, classifications made by the expert and the researcher exhibited similar characteristics. 


\section{Results}

Table 1. Comparison of Teacher Candidate's Selection and Placement Procedures in Singapore, Shanghai-China, Hong Kong-China and Turkey

\begin{tabular}{ll}
\hline Countries & Selection and Placement Procedures \\
\hline \multirow{3}{*}{ Singapore } & Teacher candidates undergo two stages in the selection and placement process. \\
& Cambridge Advanced Level Examination and an interview organized by National \\
& Institute of Education
\end{tabular}

$\begin{array}{ll}\text { Shanghai-China } & \text { Teacher candidates must take National College Entrance Examination-NCEE or } \\ \text { Gaokao. }\end{array}$

Candidates must take Diploma of Secondary Education-HKDSE, Other Learning

Hong Kong-China $\quad$ Experiences (OLE), Student Learning Profile (SLP).

Turkey

First cycle, entrance to Higher Education Exams, second cycle, entrance to Higher Education Exams taken in different fields such as mathematics, science, literature, geography, social sciences and foreign language education (ÖSYM, 2016).

(MOE, 2004; NIE, 2011; HKEAA, 2016; ÖSYM, 2016).

It can be understood in Table 1 that both similarities and differences can be observed in terms of teacher candidate's selection and placement procedures in the relevant countries. In Singapore, teacher candidates undergo two stages in the selection and placement process. At first, teacher candidates must take Cambridge Advanced Level Examination which is held twice a year. Second, candidates must attend an interview organized by National Institute of Education and they are evaluated in terms of teaching proficiency by committees mainly composed of school principals (NIE, 2011). In Shanghai-China, teacher candidates must take National College Entrance Examination-NCEE or Gaokao, they can be admitted in a teacher training program based on the exam scores without any interviews (MOE, 2016; OECD, 2016a). However, the case is different in Hong-Kong China, because candidates must take Diploma of Secondary Education-HKDSE as a central examination in addition to Other Learning Experiences (OLE) and Student Learning Profile (HKEAA, 2016). In Turkish case, high school graduates must take Entrance to Higher Education Exam at the first step and the candidates who had a passing grade take another exam in different fields such as mathematics, science, literature, geography, social sciences and foreign language education (ÖSYM, 2016). In other words, candidates who had a base point in the second step are placed in a teacher training program by Student Selection and Placement Center (ÖSYM).

Table 2. The Administrative Systems of Teacher Training Programs in the Relevant Countries

\begin{tabular}{ll}
\hline Countries & The Administrative Systems of Teacher Training Programs \\
\hline \multirow{3}{*}{ Singapore } & $\begin{array}{l}\text { Educational and teacher training policy of the country is made by Ministry of } \\
\text { National Education. These policies are executed by National Institute of Education } \\
\text { which is the only responsible authority for teacher training activities in the country. }\end{array}$ \\
Shanghai-China & $\begin{array}{l}\text { In Shanghai-China, teacher candidates must take four-year training at a university or } \\
\text { teacher training colleges. }\end{array}$ \\
Hong Kong-China & Teacher candidates must take training at four or five-year colleges or institutes. \\
Turkey & Teacher candidates are generally trained at four-year faculty of vocational or \\
& technical education.
\end{tabular}

(MOE, 2004; NIE, 2009; NCEE, 2016; YÖK, 1998, 2015).

In Singapore, educational and teacher training policy of the country is made by Ministry of National Education. These policies are executed by National Institute of Education under the umbrella of Nanyang Technology University in terms of teacher training. This autonomous institution is the only responsible authority for teacher training activities in the country. Enhanced Partnership Model is perceived in order to raise teacher quality and this 
model aims to establish a link between theory and practice by strengthening the coordination between Ministry of National Education, National Institute of Education and schools (NIE, 2009). In Shanghai-China, teacher candidates must take four-year training at a university or teacher training colleges while in-service training is provided through televisions, letters and evening schools (MOE, 2004). Similarly, in Hong-Kong China, teacher candidates must take training at four or five-year colleges or institutes (NCEE, 2016). As from Turkey, teacher candidates are generally trained at four-year faculty of vocational or technical education. In addition, the graduates of faculty of letters can be appointed as field teachers upon completion of pedagogic certificate program (YÖK, 1998, 2015).

Table 3. Requirement for Teacher Appointment in Four Countries

\begin{tabular}{ll}
\hline Countries & Requirement \\
\hline Singapore & CV, 30 percentile achievements, world knowledge test, interview and training period. \\
Shanghai-China & $\begin{array}{l}\text { A test on pedagogy, psychology, methodology and teaching proficiency, a positive } \\
\text { report given by the advisor and the board members of faculty. }\end{array}$ \\
Hong Kong- China & $\begin{array}{l}\text { Education Bureau for appointment, no national exams } \\
\text { Public Employee Selection Examination (KPSS), interview, performance evaluations } \\
\text { Turkey }\end{array}$ \\
\hline
\end{tabular}

(MOE, 2004; NIE, 2009; EB, 2010; Resmi Gazete, 2016).

In Singapore, teacher candidates are evaluated with reference to their C.Vs. Those who are considered eligible upon C.V. evaluation and placed first 30\% achievement among candidates are administrated general world knowledge test and they must be successful in this exam. Next, candidates must take an interview given by three school principals in terms of attitude, intelligence and behaviour. Then, candidates undergo a training process in National Institute of Education and are paid a salary. During this process, the professional development of the candidates is aimed and those who cannot make progress are eliminated (Bakığlu \& Göçmen, 2016; NIE, 2009). As from the case in Shanghai-China, candidates must achieve a test on pedagogy, psychology, methodology and teaching proficiency. In addition, a positive report given by the advisor and the board members of faculty is a prerequisite for the appointment (MOE, 2004). In Hong Kong-China, graduates apply for Education Bureau for appointment and they are assigned upon the evaluation instead of any national exams (EB, 2010). In Turkish case, graduates must take Public Employee Selection Examination and have a passing grade. Second, candidates must have an interview on world knowledge, general ability, content and professional knowledge. In other words, the appointment is executed by both a national exam and an interview. Those who achieved this process work as a paid teacher for a year. During this process, candidates undergo two performance evaluations and those who failed in this process are eliminated. Achievers are appointed as contracted teachers for six years and then granted permanent statue (Resmi Gazete, 2016).

Table 4. The Content of Teacher Training Programs in Four Countries

\begin{tabular}{ll}
\hline Countries & Content \\
\hline Singapore & $\begin{array}{l}\text { The courses offered are centered around pedagogy, content, language, expression and } \\
\text { teaching practices. }\end{array}$ \\
Shanghai-China & $\begin{array}{l}\text { Pedagogy and content courses are the main body of the program. } \\
\text { Courses are composed of teacher attitude, physical and mental health, classroom } \\
\text { management, team work, self-confidence, adaptation, effective communication skills } \\
\text { and socialization. In addition, English and mandarin language courses are given to } \\
\text { the teacher candidates. } \\
\text { Hong Kong-China }\end{array}$ \\
$\begin{array}{l}\text { Content knowledge }(50-60 \%), \text { pedagogic knowledge }(20-30 \%) \text { and world } \\
\text { knowledge }(10-20 \%) \text { shape the core of the program. }\end{array}$ \\
Turkey
\end{tabular}

(NIE, 2011; NCEE, 2016; MOE, 2004; YÖK, 2007).

In Singapore, the courses offered are centered on pedagogy, content, language and expression and teaching practices. As from Shanghai-China, pedagogy and content courses are the main body of the program. Although primary teacher 
training is offered at three or four-year teacher training colleges; secondary and high school teachers are trained at four-year colleges or universities (MOE, 2004). In Hong-Kong-China, courses are composed of teacher attitude, physical and mental health, classroom management, team work, self-confidence, adaptation, effective communication skills and socialization. In addition, English and mandarin language courses are given to the teacher candidates (NCEE, 2016). In Turkey, content knowledge (50-60\%), pedagogic knowledge (20-30\%) and world knowledge (10-20\%) shape the core of the program. Apart from this, candidates who are not graduates of faculty of education must have a certificate of pedagogy to serve at public schools (YÖK, 2007).

Table 5. The In-service Training of Teachers in Four Countries

\begin{tabular}{ll}
\hline Countries & In-Service Training Process \\
\hline Singapore & Teachers take 100 hours of in-service training each year. \\
Shanghai-China & Every teacher is supposed to take 240 hours of in-service training within five years. \\
& Lesson study method is a concept in in-service training which consists of two \\
lessons in each session and teacher groups come together to discuss, cooperate and \\
improve their professional performance. \\
Training seminars are conducted for two weeks in June and two weeks in \\
Turkey & $\begin{array}{l}\text { September, totally four weeks without taking into consideration the field } \\
\text { differences. }\end{array}$ \\
\hline
\end{tabular}

(Tad, 2002; Seferoğlu, 2004; MOE, 2004; MOE, 2006; Lee, 2008; NCEE, 2016).

In Singapore, teachers take 100 hours of in-service training each year. This training aims to update knowledge as life-long learners, to respond students' demand in a better way, to cope with new challenges, to adapt new teaching situations (NIE, 2009; MOE, 2006). In Shanghai-China, every teacher is supposed to take 240 hours of in-service training within five years. In-service training is shaped according to the reports of inspectors, school principals and headmasters and involves tackling teaching deficiencies. In addition, teachers are encouraged to attend masters' programs (MOE, 2004). In Hong Kong China, lesson study method is a concept in in-service training which consists of two lessons in each session and teacher groups come together to discuss, cooperate and improve their professional performance at some intervals (Tad, 2002). As from Turkey, training seminars are conducted for two weeks in June and two weeks in September, totally four weeks without taking into consideration the field differences. These seminars can also be organized through online learning (Seferoğlu, 2004).

Table 6. The Place of Teaching Practices in Teacher Training Programs in Four Countries

\begin{tabular}{ll}
\hline Countries & Teaching Practices \\
\hline Singapore & $\begin{array}{l}\text { Teaching practices are extended throughout four years. Teacher candidates go } \\
\text { teaching practices in the first grade for two weeks, in the second grade for five } \\
\text { weeks, in the third grade for five weeks and in the final year for ten weeks. }\end{array}$ \\
Teaching practices are scheduled in the fourth year and prospective teachers \\
participate in teaching practices forty hours in each semester. \\
Hong Kong-China & $\begin{array}{l}\text { Teaching practices take one year. } \\
\text { Prospective teachers go teaching practices at schools in the 6th, 7th and 8th } \\
\text { Turkey }\end{array}$ \\
\hline
\end{tabular}

(NIE, 2009; NCEE, 2016; YÖK, 1998).

In Singapore, teaching practices are extended throughout four years. Teacher candidates go teaching practices in the first grade for two weeks, in the second grade for five weeks, in the third grade for five weeks and in the final year for ten weeks. The ratio between teaching practices and whole courses is $16 \%$ (NIE, 2009). In Shanghai-China, teaching practices are scheduled in the fourth year and prospective teachers participate in teaching practices forty hours in each semester (MOE, 2004). In Hong Kong-China, teaching practices take one year (NCEE, 2016). As from Turkey, prospective teachers go teaching practices at schools in the 6th, 7th and 8th semesters as school experience and teaching practice. School experience takes place one hour at the faculty and four hours at a school to recognize 
students, teachers and the program based on interview and observation. Teaching practice is executed two hours at the faculty and four hours at a school to sharpen their teaching skills (YÖK, 1998).

\section{Discussion}

This study revealed that teacher training programs in Singapore, Shanghai-China and Hong Kong-China and Turkey exhibited both similar and different characteristics in some aspects.

\subsection{Selection Procedures of Prospective Teachers}

Singapore goes through a different selection process when compared with other three countries. Although four countries require a local or central entrance examination, Singapore is the only one which requires an additional oral interview formed by school principals (NIE, 2011). In order words, Singapore implements a different procedure and avoids only one central examination based on elimination rather than selection. In the final year of a high school, students make their choices about their future career. Candidates are accepted to teaching profession according to willingness, predisposition to profession and qualification. However, the other three countries carry out central examinations and examinees can prefer other professions in accordance with their scores from the exam. In Turkish case, candidates must only take two central exams (YGS, LYS) including all professions and this restricts the selection process for teaching profession (ÖSYM, 2016).

\subsection{Placement Procedures of Prospective Teachers}

In Shanghai-China and Hong Kong-China, pre-service teachers are trained at four or five-year colleges or institutes of education (MOE, 2004; NCEE, 2016). Accordingly, Turkey has a similar system besides the graduates of faculty of letters, science and some vocational higher schools can also have a certificate of pedagogy as a result of training program (YÖK, 1998, 2015). This causes different approaches, methods, academic qualification, world and pedagogic knowledge from one teacher to another. Whereas, Singapore trains all teacher candidates at NIE where necessary theory and practice for teaching skills are acquired in this center. This leads to standardization and quality in teaching business all over the country.

Firstly, two different types of teacher training programs in Turkey pave the way for different understandings, measurement and evaluation processes, learning environments, broad-based learning understanding and information technologies. This case hinders to structure a comprehensive understanding. Secondly, the abundance of faculty of education in Turkey and the decentralization of education prevent an effective selection process and lack of standardization in quality. When this analysis is linked with PISA scores of Turkey (OECD, 2004, 2006, 2010, 2014, 2016b), Turkey has not made a remarkable progress and this failure can be associated with the teacher quality. As a result, the quality of pre-service training should be raised in a multi-dimensional way to boost teacher quality in Turkey.

\subsection{Appointment Procedures of Prospective Teachers}

Appointment process change from one country to another and they follow some selective criteria at different levels. It is understood that Singapore implements a longer and more comprehensive procedure in comparison with other three countries. C.V, first $30 \%$ graduates, world knowledge test, interview and paid monitoring period generate more productive outcome. The case in Shanghai and Hong Kong China is mainly based on exams and an interview in some cases. As from Turkey, graduates are appointed as candidate teachers with a salary, though they take a nation-wide central exam and an interview. Singapore, Shanghai-China and Turkey show similarities in terms of performance tests, interview, written exams and testing period. Six-year testing period as a contracted teacher and then appointment as a permanent staff is only applicable in Turkish context.

This testing period as contracted teacher offers several disadvantages such as lack of motivation and dissatisfaction, because they cannot be appointed somewhere else, cannot be a manager, cannot progress in payment grade, cannot have a family allowance etc. (Karadeniz \& Demir, 2010). 861.919 teacher candidates took a nation-wide central exam (KPSS) between 2009 and 2016 in Turkey, however, only 202.438 of them (almost one-fourth) were appointed as contracted or permanent teachers. In other words, 659.481 teacher candidates have been unemployed or work in different sectors (MEB et al., 2016). In some cases, those who are appointed as contracted teachers can also be assigned in a province in need by local authorities for a short term with a lower payment. This case reveals that there are different characteristics of teachers in terms of statue, payment, administrative affairs etc. It causes de-motivated teachers and reduces the quality of education (Öğ̈̈lmüş et al., 2013). PISA result of Turkey can be a sign of revising teacher employment because motivated teachers play one of the most important roles in the quality of an education system (OECD, 2010, 2014, 2016b). As a result, it is suggested that statue of contracted teacher be removed or the 
factors causing de-motivation be eliminated in Turkish context.

\subsection{Pre-service Training Procedures of Prospective Teachers}

Pre-service training period can be considered as the most important of all stages. In other words, this period involves academic, professional and pedagogic courses which constitute the main body of all process (Day \& Gu, 2010; Kavcar, 2002). While professional knowledge is given priority during pre-service training in Hong Kong-China; content knowledge, teaching practice, pedagogic courses including Chinese language, culture and history are the core of the training program in Shanghai-China (Bakioğlu \& Özcan, 2016). As from Turkish context, developing content, professional and world knowledge is the main objective of the program. In addition, the program for the certificate of pedagogy is the other way of teacher training in Turkey.

This certification program was started by The Council of Turkish Higher Education (YOK) in 2010. This Council allows some universities to open this program for graduates of faculty of science and letters (Yapıc1 \& Yapıc1, 2013). However, this program is criticized by some researchers, because candidates consider the program inefficient, intensive and non-functional. In addition, lack of appropriate materials, coordination between colleagues and insufficient practice, inconvenience of time and conditions, shortcomings of distance learning and monitoring are stated as the other reasons for the failure (Bağçeci et al., 2015; Demirtaş \& Kırbaç, 2016). Therefore, this type of certification programs can reduce the quality of an education system though it provides employment for some graduates of other faculties.

\subsection{In-service Training Procedures of Prospective Teachers}

In-service training exhibits different characteristics in four countries. While Singapore offers 100 hours of in-service training, Shanghai-China restricts this training 48 hours in a year. In Turkish context, this training takes 90 hours a year. In other words, Singapore allocates time almost twice as much as Shanghai-China. As from Hong Kong China, Lesson Study Model is used in-service training. This model suggests that group discussions at some intervals, 10-15 hours within 4-5 weeks, provide more productive feedback for teachers. In this model, teachers cooperate about objectives, methods, plans and practices about ongoing lessons (Lewis \& Perry, 2014).

Even though teachers in Turkey take a considerable amount of time in-service training, it is stated that the physical atmosphere is not appropriate, the process is not productive, and problems emerge in practices (Önen et al., 2009). This situation reduces the effectiveness of in-service training. Therefore, it is suggested that a lesson study model like Hong Kong China case can be a good model for Turkish context, because an in-service training twice a year, in September and June, can be considered rare and unproductive, but frequent cooperation groups help to find more immediate and productive solutions for emerging troubles during the teaching process.

\subsection{Teaching Practice Procedures of Prospective Teachers}

Although teaching practices in Singapore are extended throughout four years, other three countries place teaching practices in the third and fourth years of pre-service training. In Turkish context, teaching practices are implemented in the final year in two semesters as school experience ( 70 hours) and teaching practice ( 84 hours). In other words, practice period in three countries takes almost one year except Singapore. Researchers state some problems related to teaching practices in Turkish context as follows: Candidates are not able to transfer theory into practice, senior teachers and candidates cannot interact in an effective way, candidates cannot assume responsibility due to senior teachers and they cannot concentrate in teaching practices. In addition, disagreement between classroom management, methods, presentation, misuse of teaching materials, insufficient support of school principals and senior teachers, indifference to individual differences, outnumber of students in the classroom, the lack of supervision and schools are the other factors causing failure in teaching practices (Demircan, 2007; Baştürk, 2009; Koç \& Yıldız, 2012; Yapıcı \& Yapıcı, 2004). It is suggested that extension of practice period throughout the program, as in Singapore case, may help to overcome some of these problems in a short term.

\section{Acknowledgements}

E.Ç and E.S. participated in designing the data collection instruments, performed data collection and analyses, drafted the manuscript. E.Ç and E.S performed data collection, participated in designing the instruments, reviewed and revised the manuscript. E.Ç conceptualized and designed the study, designed the data collection instruments, coordinated and supervised data collection, critically reviewed the manuscript. All authors approved the final manuscript as submitted.

\section{References}


Aaronson, D., Barrow, L., \& Sander, W. (2007). Teachers and student achievement in the Chicago public high schools. Journal of Labor Economics, 25(1), 95-135. https://doi.org/10.1086/508733

Aykaç, N. (2004). Öğretme ve ögrenme sürecinde aktif ögretim yöntemleri. Ankara: Naturel.

Bağçeci, B., Yıldırım, İ., Kara, K., \& Keskinpalta, D. (2015). Pedagojik formasyon ve eğitim fakültesi öğrencilerinin öğretmenlik mesleğine yönelik tutumlarının karşılaştırılması. Erzincan Üniversitesi Eğitim Fakültesi Dergisi, 17(1), 307-324. https://doi.org/10.17556/jef.52416

Bakioğlu, A., \& Göçmen, G. (2016). Singapur eğitim sistemi. In A. Bakioğlu (Ed.), Karşılaştırmalı eğitim yönetimi: PISA'da başarılı olan ülkelerin eğitim sistemleri. (pp. 127-155). Ankara: Nobel.

Bakioğlu, A., \& Özcan, M. (2016). Çin (Şanghay) eğitim sistemi. In A. Bakioğlu (Ed.), Karşılaştırmalı eğitim yönetimi: PISA'da başarılı olan ülkelerin eğitim sistemleri. (pp. 1-40). Ankara: Nobel.

Baştürk, S. (2009). Investigating teaching practice course according to student teachers’ opinions. Elementary Education Online, 8(2), 439-456.

Borich, G. D. (2014). Effective teaching methods: Research-based practice. Ankara: Nobel.

Çepni, S. (2010). Araştırma ve proje çalışmalarına giriş. Trabzon: Akademi.

Day, C., \& Gu, Q. (2010). The new lives of teachers. London: Routledge.

Demaray, M. K., \& Elliott, S. N. (1998). Teachers' judgments of students' academic functioning: A comparison of actual and predicted performances. School Psychology Quarterly, 13(1), 8-24. https://doi.org/10.1037/h0088969

Demircan, C. (2007). Okul deneyimi II dersine yönelik öğrenci görüşlerinin incelenmesi (Mersin Üniversitesi Örneği). Mersin Üniversitesi Eğitim Fakültesi Dergisi, 3(2), 119-132.

Demirtaş, H., \& Kırbaç, M. (2016). Pedagojik formasyon sertifika programı öğrencilerinin pedagojik formasyon eğitimine ilişkin görüşleri. Trakya Üniversitesi Eğitim Fakültesi Dergisi, 6(2), 137-152.

Education Bureau (EB) (2010). Appointment and related matters. Retrieved from http://www.edb.gov.hk/ en/sch-admin/admin/about-schstaff/ index.html.

Ehrenberg, R., \& Brewer, D. (1995). Did teachers' verbal ability and race matter in the 1960's? Coleman revisited. Economics of Education Review 141, 1-21. https://doi.org/10.1016/0272-7757(94)00031-Z

Flick, U. (2009). An introduction to qualitative research. London: Sage.

Gopinathan, S., \& Sharpe, L. (2007). The teacher is the key: Professionalism and the strategic state. In E. Thomas (Ed.), Teacher education dilemma and prospects. (pp. 23-33). London: Routledge.

Grossman, P. L. (1990) The making of a teacher: Teacher knowledge and teacher education. London: Teachers College Press.

Harris, D. H., \& Sass, T. R. (2011). Teacher training, teacher quality and student achievement. Journal of Public Economics, 95(7), 798-812. https://doi.org/10.1016/j.jpubeco.2010.11.009

Hong Kong Examinations and Assessment Authority (HKEAA) (2016). Hong Kong Diploma and Secondary Education-HKDSE. Retrieved from http://www.hkeaa.edu.hk/en/hkdse/.

Karadeniz, Y., \& Demir, S. B. (2010). Sözleşmeli öğretmenlik uygulamasının değerlendirilmesi. Ondokuz Mayıs Üniversitesi Eğitim Fakültesi Dergisi, 29(2), 55-77.

Kavcar, C. (2002). Cumhuriyet döneminde dal öğretmeni yetiştirme. Ankara Üniversitesi Ĕ̌itimi Bilimleri Fakültesi Dergisi, 35(1-2), 1-14.

Koç, C. \& Yıldız, H. (2012). Öğretmenlik uygulamasının yansıtıcıları: günlükler. Eğitim ve Bilim, 37(164), $223-236$.

Krolak-Schwerdt, S., Glock, S., \& Böhmer, M. (2014). Introduction. In S. Krolak-Schwerdt, S. Glock, S., \& M. Böhmer (Eds.), Teachers' professional development assessment, training, and learning. (pp. 1-5). Rotterdam: Sense Publishers.

Lee, J. F. K. (2008). A Hong Kong case of lesson study-benefits and concerns. Teaching and Teacher Education, 24(5), 1115-1124. https://doi.org/10.1016/j.tate.2007.10.007

Lewis, C., \& Perry, R. (2014). Lesson study with mathematical resources: A sustainable model for locally-led teacher professional learning. Mathematics Teacher Education ve Development, 16(1), 1-20. 
MEB İnsan Kaynakları Genel Müdürlüğü (2016). İstatistiki bilgiler. Retrieved from http://sgb.meb.gov.tr/www/resmi-istatistikler/icerik/64.

Ministry of Education of The People's Republic of China (MOE) (2004). Retrieved from http://www.moe.edu.cn/english/basic_b.htm.

Ministry of Education of The People's Republic of China (MOE) (2004). National College entrance examination. Retrieved from http://www.moe.edu.cn/publicfiles-/business/htmlfiles/moe/moe 2792/.

National Center on Education and the Economy (NCEE) (2016). Teacher and principal quality. Retrieved from http://www.ncee.org/programs-affiliates/center-on-international-educationbenchmarking/top-performing-countri es/hong-kong-overview/hong-kong-teacher-and-principal-quality/.

Neuman, W. L. (2007). Qualitative and quantitative approaches. Boston: Pearson Education.

NIE. (2009). A Teacher Education Model for the 21st Century. A Report by the National Institute of Education, Singapore. Retrieved from http://www.nie.edu.sg-/files/about-nie/TE21\%20online\%20version.pdf.

NIE. (2011). BABSC Handbook. National Institute of Education, Singapore. Retrieved from http://www.nie.edu.sg/files/ote/Handbooks/BABSC_2011-2012_as_at_29\%20Nov\%202011.

OECD (2004). Learning for tomorrow's world. First results from PISA 2003. OECD Publishing.

OECD (2006). PISA 2006 Results: Science competencies for tomorrow's world (Volume I). OECD Publishing.

OECD (2010). PISA 2009 Results: What students know and can do: Student performance in reading, mathematics and science (Volume I). OECD Publishing.

OECD (2014). PISA 2012 Results: What students know and can do - Student performance in mathematics, reading and science (Volume I). OECD Publishing.

OECD (2016a). Education in China: A snapshot. OECD Publishing.

OECD (2016b). PISA 2015 Results excellence and equity in education. Volume I, Retrieved from http://www.oecd.org/dataoecd.

Öğülmüş, K., Yıldırım, N., \& Aslan, G. (2013). Ücretli öğretmenlerin görevlerini yaparken karşılaştıkları sorunlar ve ücretli öğretmenlik uygulamasının okul yöneticilerince değerlendirilmesi. İlköğretim Online, 12(4), 1086-1099.

Oğuzkan, F. (1974). Eğitim terimleri sözlüğ̈̈. Ankara: Türk Dil Kurumu Yayınları.

Ölçme Seçme ve Yerleştirme Merkezi (ÖSYM) (2016). Yükseköğretim Programlarına Alınacak Öğrencilerin Seçimi İ̧̧in Öğrenci Seçme ve Yerleştirme Sistemi. Retrieved from http://www.osym.gov.tr/TR,8832/hakkinda.html.

Önen, F., Mertoğlu, H., Saka, M., \& Gürdal, A. (2009). Hizmet içi eğitimin öğretmenlerin öğretim yöntem ve tekniklerine ilişkin bilgilerine etkisi: Öpyep örneği. Ahi Evran Üniversitesi Kırşehir Eğitim Fakültesi Dergisi, 10(3), 9-23.

Resmi Gazete (2016). Sözleşmeli öğretmen istihdamina ilişkin yönetmelik. Retrieved from http://www.resmigazete.gov.tr/eskiler/2016/08/20160803-22.htm

Richman, S. D., Permuth, S., \& Richman, P. M. (2013). Successful teaching: Practical ideas and enabling questions. New York: R\&L Education.

Rivkin, S., Hanushek, E., \& Kain, J. (2005). Teachers, schools, and academic achievement. Econometrica, 73(2), 417-458. https://doi.org/10.1111/j.1468-0262.2005.00584.x

Seferoğlu, S. S. (2004). Öğretmen yeterlilikleri ve mesleki gelişimi. Bilim ve Aklın Aydınlığında Eğitim, 58, 40-45.

Şişman, M. (2009). Teacher's competencies: A modern discourse and the rhetoric. Inonü University Journal of the Faculty of Education, 10(3), 63-82.

Skinner, D. (2005). Teacher Training. Edinburg: Edinburg University Press.

Sönmez, V. (2003). Öğretmenlik mesleğine giriş. Ankara: Anı Yayıncılık.

Tad, W. (2002). Learning from Japanese lesson study. Educational Leadership, 59(6), 36-39.

Weber, R. F. (1990). Basic content analysis: Quantitative applications in the social sciences. London: SAGE. https://doi.org/10.4135/9781412983488

Yapıcı, M., \& Yapıcı, Ş. (2013). Öğretmen adaylarının pedagojik formasyona ilişkin metaforları. Turkish 
Studies-International Periodical for The Languages, Literature and History of Turkish or Turkic, 8(8), 1421-1429.

Yapıcı, Ş., \& Yapıcı, M. (2004). Öğretmen adaylarının okul deneyimi I dersine ilişkin görüşleri. İlköğretim Online, 3(2), 54-59.

YÖK (1998). Eğitim fakülteleri ögrretmen yetiştirme programlarının yeniden düzenlenmesi. Ankara: Yükseköğretim Kurumu Başkanlı̆̆ı.

YÖK (2007). Öğretmen yetiştirme ve eğitim fakülteleri (1982-2007). Retrieved from http://www.yok.gov.tr/documents/10279/30217/yok_ogretmen_kitabi/054a8c72-174b-4b00-a675-837874006db 5

YÖK (2015). Pedagojik formasyon eğitimi sertifika programına ilişkin çerçeve usul ve esaslar. Retrieved from http://www.yok.gov.tr/web/guest/icerik//journal_content/-56_INSTANCE_rEHF8BIsfYRx/10279/20361248

\section{Note}

The paper is presented as a abstract at the 26th International Conference on Educational Sciences in Turkey. 